\title{
ДІДЖИТАЛІЗАЦІЯ ПРОВЕДЕННЯ ТОРГОВИХ РОЗСЛІДУВАНЬ І НОРМАТИВНА МОДЕЛЬ ОБМЕЖЕННЯ МОНОПОЛІЗМУ В ГОСПОДАРСЬКІЙ ДІяЛЬНОСТІ
}

\author{
ОЗЕРАНСЬКА Світлана Іванівна - здобувач кафедри господарського та \\ трУдового права МАУП
}

DOI 10.32782/LAW.UA.2021.4.23

Економічна конкурениія $\varepsilon$ необхідною умовою функиіонування здорового ринкового середовища. Ось чому запровадження $i$ захист конкурентних відносин є одним з державних пріоритетів, а ефективне правове забезпечення обмеження монополізму в господарсъкій діяльності - дієвим засобом досягнення иієі мети. Міністерство економіки Украӥни готуе IT-платборму «Державний інбормаиійносервісний портал «Торговельний захист України». У той же час комп'ютеризачія будь-яких управлінських процесів буде ефбективною лише за умови, коли правові акти, які регламентують (бактично, бормалізують) процеси, щзо підлягають комп'ютеризації, - $є$ досконалими, тобто відповідають певним вимогам. Інакше ефбективність комп'ютеризаиї буде низькою. Сукупність юридичних норм, що складають правове забезпечення обмеження монополізму в господарсъкій діяльності позначаються терміном «нормативна модель обмеження монополізму». Надзвичайно важливими вважаємо авторські пропозищй щодо закріплення в законі про олігархів заходів стосовно відміни рішень, прийнятих на догоду олігарху з наступним покаранням відповідних службовиів і самого олігарха.

Ключові слова: економічна конкурениія, здорове ринкове середовище, діджіталізаиія, захист конкурентних відносин, ефективність правового забезпечення обмеження монополізму, нормативна модель, торговельні розслідування.
Актуальність проблеми

Економічна конкуренція є необхідною умовою функціонування здорового ринкового середовища. Ось чому запровадження і захист конкурентних відносин є одним 3 державних пріоритетів, а ефективне правове забезпечення обмеження монополізму в господарській діяльності - дієвим засобом досягнення цієї мети.

Як відомо, Міністерство економіки України готує IT-платформу «Державний інформаційно-сервісний портал «Торговельний захист України». Ця IT-платформа розробляється за підтримки Програми USAID «Конкурентоспроможна економіка України» 3 метою удосконалення роботи в рамках торговельних розслідувань/переглядів (антидемпінгових, антисубсидиційних, спеціальних). Цей програмний продукт призначений для автоматизації процесу проведення торговельних розслідувань/переглядів у країні та участі у них заінтересованих сторін, спрощення процесу подання та обміну інформацією і матеріалами в рамках торговельних розслідувань, забезпечення публічного доступу до інформації та матеріалів, які стосуються використання інструментів торговельного захисту. Готується інформація про процедурні етапи використання ITплатформи в рамках участі в торговельних розслідуваннях.

У той же час комп'ютеризація будь-яких управлінських процесів буде ефективною лише за умови, коли правові акти, які регламентують (фактично, формалізують) проце- 
си, що підлягають комп’ютеризації, - є досконалими, тобто відповідають певним вимогам. Інакше ефективність комп'ютеризації буде низькою.

Таким чином, правове забезпечення повинно відповідати певним вимогам до нього. Інакше воно не буде по-справжньому дієвим. Це вимоги повноти і достатності, внутрішньої узгодженості норм, що включаються до правового регулювання відповідних відносин, його ефективність тощо.

Аналіз фактичного стану правового регулювання відносин з обмеження монополізму в господарській діяльності свідчить, що воно не відповідає вищезазначеним вимогам, що і обумовлює актуальність цього дослідження.

\section{Аналіз останніх досліджень і публікацій}

Питання правового забезпечення захисту економічної конкуренції, юридичної відповідальності за іiі порушення, поширення монополістичної діяльності порушувалися в працях таких учених, як: А.Ю. Атаманова, А. Г. Бобкова, С.С.Валітов, Б.В. Деревянко, Г.Д. Джумагельдієва, Р. А. Джабраілов, Д.В. Задихайло, О.Р. Зельдіна, П.С. Матвеєв, В. С. Мілаш, С.А. Паращук, О.П. Подцерковний, К.Ю. Тотьєв, В.А. Устименко, Б.В. Шуба, В.С. Щербина та ін.

Значно менше уваги приділяється питанням ефективності правового забезпечення обмеження монополізму в господарській діяльності, вимогам до цього забезпечення. Ще менше авторів системно підходИть до досліджень нормативної моделі як сукупності правових актів, що регулюють відповідні відносини, вимогам до неї.

\section{Мета статті}

Метою статті є започаткування підходу до підвищення якості правового регулювання обмеження монополізму в господарській діяльності, як умови дієвості цього регулювання, можливості діджиталізації цього процесу (обмеження монополізму).

Основні результати дослідження

Зрозуміло, що правове забезпечення повинно відповідати певним вимогам до ньо- го. Інакше воно не буде по-справжньому дієвим. Це вимоги повноти і достатності, узгодженості правового регулювання відповідних відносин, його ефективності тощо.

Аналіз фактичного стану правового регулювання відносин 3 обмеження монополізму в господарській діяльності свідчить, що воно не відповідає зазначеним вимогам.

Держава проводить курс на діджиталізацію управлінських операцій, в т.ч. діджиталізацію торговельних розслідувань (Постанова КМ №179 від 3 березня 2021 р. «Про затвердження Національної економічної стратегії на період до 2030 року»). Особливо актуальною є ця задача у зв'язку з пандемією (COVID-19). Про це прямо сказано у Програмі стимулювання економіки для подолання наслідків COVID-19: «Економічне відновлення». У цій програмі також йдеться про діджіталізацію торговельних розслідувань (див. розділ «Нові соціальні стандарти. Серед населення існує культура поводження в умовах пандемії, перехід до безконтактної економіки»).

Сукупність юридичних норм, що складають правове забезпечення обмеження монополізму в господарській діяльності, ми позначаємо терміном «нормативна модель обмеження монополізму», під якою (моделлю) розуміється сукупність несуперечливих, узгоджених між собою нормативно-правових актів, що регулюють процеси обмеження монополізму, демонополізації економіки, антимонопольного регулювання, контролю за дотриманням законодавства про захист економічної конкуренції; захисту інтересів суб'єктів господарювання, груп суб'єктів господарювання та споживачів від його порушень.

Нормативна модель обмеження монополізму, з точки зору галузевої належності актів, які включаються до ії складу - носить комплексний характер. Тобто до складу згаданої моделі відносяться не тільки такі комплексні акти, як закони України «Про захист від недобросовісної конкуренції», «Про захист економічної конкуренції, а й акти адміністративного («Про Антимонопольний комітет України», Кодекс України про адміністративні правопорушення), кримінального (антикорупційного) права тощо. 


\section{Цивільне, підприсмницьке, господарське та трудове право}

Правові засади обмеження монополізму, забезпечення захисту економічної конкуренції закладені в таких нормативно-правових актах, як Конституція України, Господарський кодекс та закони України «Про Антимонопольний комітет України», «Про захист від недобросовісної конкуренції», «Про захист економічної конкуренції.

Згідно зі статтею 42 Конституції України не допускаються зловживання монопольним становищем на ринку, неправомірне обмеження конкуренції та недобросовісна конкуренція. Види і межі монополії визначаються законом. Статтею 92 Основного Закону передбачено, що тільки законами України визначаються правила конкуренції та норми антимонопольного регулювання.

Господарсько-правові засади підтримки та захисту економічної конкуренції, обмеження монополізму в господарській діяльності містяться у Господарському кодексі та вищезазначених законах. Зокрема, у Господарському кодексі України питанням обмеження монополізму присвячені положення ст. ст. 25 -29 глави 3 «Обмеження монополізму та захист суб'єктів господарювання і споживачів від недобросовісної конкуренції». Згідно зі ст. 27 «Обмеження монополізму в економіці» «монопольним визнається домінуюче становище суб'єкта господарювання, яке дає йому можливість самостійно або разом 3 іншими суб'єктами обмежувати конкуренцію на ринку певного товару (робіт, послуг)» (п. 1). Монопольним є становище суб'єкта господарювання, частка якого на ринку певного товару перевищує розмір, встановлений законом. Монопольним може бути визнано також становище суб'єктів господарювання на ринку товару за наявності інших умов, визначених законом (п. 2,3$)$. У разі суспільної необхідності та з метою усунення негативного впливу на конкуренцію, сказано у п. 4 цієї статті, органи державної влади здійснюють стосовно сучасних монопольних утворень заходи антимонопольного регулювання відповідно до вимог законодавства та заходи демонополізації економіки, передбачені відповідними державними програмами, за винятком природних монополій. П. 5 ст. 27 органам державної влади та органам місцевого самоврядування забо- роняється приймати акти або вчиняти дії, спрямовані на економічне посилення наявних суб'єктів господарювання-монополістів та утворення без достатніх підстав нових монопольних утворень, а також приймати рішення про тільки централізований розподіл товарів.

Згідно зі ст. 29 «Зловживання монопольним становищем на ринку» таким зловживанням вважаються: «нав’язування таких умов договору, які ставлять контрагентів у нерівне становище, або додаткових умов, що не стосуються предмета договору, включаючи нав'язування товару, не потрібного контрагенту; обмеження або припинення виробництва, а також вилучення товарів 3 обороту з метою створення або підтримки дефіциту на ринку чи встановлення монопольних цін; інші дії, вчинені з метою створення перешкод доступу на ринок (виходу з ринку) суб'єктів господарювання; встановлення монопольно високих або дискримінаційних цін (тарифів) на свої товари, що призводить до порушення прав споживачів або обмежує права окремих споживачів; встановлення монопольно низьких цін (тарифів) на свої товари, що призводить до обмеження конкуренції.

Закон України «Про захист економічної конкуренції» визначає економічну конкуренцію як змагання між суб'єктами господарювання 3 метою здобуття завдяки власним досягненням переваг над іншими суб'єктами господарювання, внаслідок чого споживачі, суб'єкти господарювання мають можливість вибирати між кількома продавцями, покупцями, а окремий суб'єкт господарювання не може визначати умови обороту товарів на ринку. конкуренція виступає фундаментальним елементом ринку, завдяки якому досягається збалансованість між попитом і пропозицією. Суб'єкти господарювання, органи влади, органи місцевого самоврядування, а також органи адміністративно-господарського управління та контролю зобов'язані сприяти розвитку конкуренції та не вчиняти будь-яких неправомірних дій, які можуть мати негативний вплив на конкуренцію.

Визначення монопольного (домінуючого) становища суб'єктів господарювання має 
здійснюватися згідно з відповідною методикою, затвердженою розпорядженням Антимонопольного комітету України від 5 березня 2002 р. [1].

Щодо суперечливості у правовому регулюванні торговельних розслідувань. У юридичній спільноті загострилася суперечність між доцільністю підтримки національного виробника і захистом конкуренції. Великий бізнес зацікавлений у захисті від недобросовісного імпорту, середній бізнес хоче мати можливість купувати дешевший імпортний товар. Тому торгово-обмежувальні розслідування практично завжди конфліктують із цілями конкурентної політики. Мета антидемпінгових мит і квот - обмежити доступ імпортної продукції на ринок під приводом боротьби 3 дешевим імпортом. Водночас здешевлення продукції для споживачів і нульові бар'єри для входу на ринок є метою конкурентної політики будь-якої держави. Питання узгодження відповідних правових актів стає дедалі актуальнішим. В останні роки почастішали випадки, коли Антимонопольний комітет України, що має право голосу щодо впровадження обмежувальних заходів, не підтримує пропозиції Мінекономіки про їх впровадження [2].

Стосовно повноти правового регулювання. Правове забезпечення обмеження монополізму в господарській діяльності спрямоване, як правило, не проти монополістів, а проти монопольного захоплення ними ринку (товару, послуг). Це забезпечення повинно вирішувати проблеми монопольної змови, монополії цін, проблеми поглинання монополістами слабших конкурентів. Однак незрівнянно більшу загрозу національній безпеці створюють олігархи. Закон «Про запобігання загрозам національній безпеці, пов’язаних 3 надмірним впливом осіб, які мають значну економічну або політичну вагу в суспільному житті (олігархів)» мав би вирішувати відповідну проблему - проблему подолання олігархічної суті держави Україна. Закон про олігархів повинен підсилювати їх відповідальність, оскільки вони мають незрівнянно більше можливостей для підкупу влади, здійснення інших вищезазначених небезпечних діянь.

Суспільна небезпечність олігархів щодо підкупу зростає пропорційно росту згада- них можливостей, загрожуючи національній безпеці. Це і мають віддзеркалювати санкції за відповідні дії олігарха. Отже, закон про олігархів мав би адекватно посилювати юридичну відповідальність за підкуп, розширювати перелік суспільно небезпечних діянь олігархату, які повинні підлягати покаранню. Крім того, закон мав би суттево підвищувати відповідальність продажних можновладців, чиновників, які діють в інтересах олігарха. До таких діянь слід віднести лобіювання законопроєктів, нецільове спрямування, використання, розкрадання коштів держбюджету, забезпечення призначення своїх ставлеників і т.д. і т.п.

Як уже зазначалось, Міністерство економіки України, з метою удосконалення роботи в рамках торговельних розслідувань/переглядів (антидемпінгових, антисубсидиційних, спеціальних), розробляє IT-платформу «Державний інформаційно-сервісний портал «Торговельний захист України».

Закон про олігархів не тільки містить їх ознаки, але й визначає порядок, алгоритм визнання осіб такими. Чим більш деталізовано будуть виписані відповідні параметри, дії, тим відповідні процеси будуть більш формалізованими. А отже, i такими, які може виконати комп'ютер, без участі людини. Відомо, що зменшення питомої ваги людського фактору сприятиме підвищенню об'єктивності процесу, його незалежності від суб'єктивізму, властивому людині.

Надзвичайно важливими вважаємо авторські пропозиції щодо закріплення в законі про олігархів заходів стосовно відміни рішень, прийнятих на догоду олігарху з наступним покаранням відповідних службовців і самого олігарха. Оскільки жодна чинна влада не захоче приймати (підписувати) такий закон, то тому його прийняття доцільно було $б$ перенести до умов укладання суспільного договору - передвиборних умов для кандидата у президенти. Такі умови повинні стати обов'язковими для обраної особи. А їх невиконання повинно призводити до автоматичного відсторонення обранця i до призначення наступних виборів.

Викладене стосується достатності, повноти нормативної моделі обмеження монополізму в господарській діяльності. 


\section{Цивільне, підприсмницьке, господарське та трудове право}

\section{Висновки}

Перехід до конкурентних засад в економіці, забезпечення становлення і функціонування здорового ринкового середовища, запровадження і захист конкурентних відносин - є одним 3 державних пріоритетів. Доцільно системно підходити до правового забезпечення обмеження монополізму, виділяючи нормативну модель і організаційно-правові засоби іï реалізації. Крім того(і це також важливо), правове забезпечення обмеження монополізму має бути систематизованим, достатнім та внутрішньо узгодженим.

\section{Література}

1. Методика визначення монопольного (домінуючого) становища суб'єктів господарювання, затв. розпорядженням Антимонопольного комітету України від 5 березня 2002 р. No 49-р. Офіційний вісник України. 2002. No 14

2. Шершун С., Лахно С. Конкуренція і торговельні розслідування: хто переможе // Юридична газета/ https://yur-gazeta.com/ publications/practice/inshe/konkurenc

\section{Reference}

1. Metodyka vyznachennya monopol'noho (dominuyuchoho) stanovyshcha sub"yektiv hospodaryuvannya, zatv. rozporyadzhennyam Antymonopol'noho komitetu Ukrayiny vid 5 bereznya 2002 r. No 49-r. Ofitsiynyy visnyk Ukrayiny. 2002. No 14

2. Shershun S., Lakhno S. Konkurentsiya i torhovel'ni rozsliduvannya: khto peremozhe // Yurydychna hazeta/ https://yur-gazeta.com/ publications/practice/inshe/konkurenc

Ozeranska Svitlana Ivanivna, applicant of the Department of Economic and Labor Law MAUP

DIGITALIZATION OF TRADE INVESTIGATIONS AND NORMATIVE MODEL OF MONOPOLISM RESTRICTION IN ECONOMIC ACTIVITY

Economic competition is a necessary condition for a healthy market environment.
That is why the introduction and protection of competitive relations is one of the state priorities, and effective legal support to limit monopolies in economic activity - an effective means of achieving this goal. The Ministry of Economy of Ukraine is preparing an IT platform for the State Information and Service Portal "Trade Protection of Ukraine". At the same time, the computerization of any management process will be effective only if the legal acts that regulate (actually, formalize) the processes to be computerized - are perfect, that is, meet certain requirements. Otherwise, the efficiency of computerization will be low.

Legal support must meet certain requirements. Otherwise it will not be truly effective. These are the requirements of completeness and sufficiency, internal coherence of the norms included in the legal regulation of the relevant relations, its effectiveness, and so on. The state pursues a course of digitalization of management operations, including digitalization of trade investigations. This problem is especially relevant in the context of the pandemic (COVID-19). The set of legal norms that make up the legal provision of restriction of monopoly in economic activity is denoted by the term "normative model of restriction of monopoly". We consider extremely important the author's proposals to enshrine in the law on oligarchs measures to overturn decisions taken in favor of the oligarch, followed by the punishment of the relevant officials and the oligarch himself. Since no current government wants to adopt (sign) such a law, it would be appropriate to postpone its adoption to the conditions of concluding a social contract - pre-election conditions for a presidential candidate. Such conditions should become mandatory for the selected person. And their non-fulfillment should lead to the automatic removal of the elected candidate and to the appointment of the next elections.

Key words: economic competition, healthy market environment, digitalization, protection of competitive relations, efficiency of legal support for restriction of monopoly, normative model, trade investigations. 